\title{
PROBLEMS AND PERSPECTIVES OF DEVELOPMENT OF COMPLEX OF COLLECTION AND TRANSPORTATION OF MUNICIPAL SOLID WASTE IN SAINT-PETERSBURG
}

\author{
Dmitrii Vakulenko \\ Mikhail Fedorov \\ Vasilii Rud' \\ Alexey Cheremisin \\ Dmitrii Schwarz \\ Saint-Petersburg State Polytechnical University, Russia
}

\begin{abstract}
For today there is a number of undecided issues on collection and transportation of waste in Saint-Petersburg and North-Western Region of Russian Federation. For modemization of a whole cycle of waste handling from the stages of collection, sorting and transportation till waste treatment, storage and burial, it has been conducted by enterprises and scientists of Saint-Petersburg a range of works directed to raising efficiency of these processes and modemization of existing equipment. When developing sorting refuse at the reloading stations, in particular it is planned to switch from primitive manual sorting to mechanic tools. There are being carried out the works on improving and development of new machinery and containers, in particular on designing new types of containers (compactors), on equipping transport by navigation systems etc. Now there is being created at the enterprise "Spetstrans" the car for service of Saint-Petersburg Center as a district of low buildings. The special attention by the specialists of motor transportation enterprises Nol and No6 is paid to turn to double-stage method of waste removal with using waste reloading stations, to designing various technological equipment for compacting and pressing waste. And it is very important because through reloading stations passes up till $50 \%$ of registered waste general volume. There are established 16 presses with compression coefficient from 4 till 8 at the reloading stations. So, the enterprises are interested themselves in raising manufacturability of process, development of new mechanisms and equipment, in introducing of computers and automated systems to the process because a concurrence for waste treatment is raised lately. This fact is necessary to take into account when planning the capacities designed for construction in the planned period.
\end{abstract}

This presentation is just devoted to analysis of enumerated problems and ways of their solving. 


\section{KEYWORDS}

Municipal Solid Waste; Collection; Transportation; Removal; Used Equipment, Technologies and Methods

\section{BRIEF CHARACTERISTICS OF THE SYSTEM OF HANDLING WITH MUNICIPAL SOLID WASTE (MSW) IN SAINT-PETERSBURG}

According to approximate expert estimations, total amount of municipal solid waste (MSW) of Saint-Petersburg is about 9.8 millions $\mathrm{m}^{3}$ [2]. From this amount 5.6 million $\mathrm{m}^{3}$ are the MSW, forming by population, as well as by municipal institutions (schools, hospitals, terminal stations etc), and remaining part $\left(4.2\right.$ millions $\left.\mathrm{m}^{3}\right)$ are the waste of small business and market (so called "commercial" waste), as well as large-sized refuse (waste) (LSR). The main part of "commercial" waste (till $80 \%$ ) is directed directly to the system of secondary raw materials collection, avoiding the enterprises of housing-and-municipal economy (HME), or are removed to the small oblast landfills, and nearly $20 \%$ of these waste $\left(0.9\right.$ millions $\left.\mathrm{m}^{3}\right)$ are removed together with MSW by city municipal services. By these services there are removed $50 \%$ of LSR. So, through the system of HME in Saint-Petersburg pass for 1 year 6.5 million $\mathrm{m}^{3}$ of MSW [2].

If rate of increase of MSW formation will keep quite high, in 2014 according to the prognosis, there is expected in the city, formation of 12.7 millions $\mathrm{m}^{3}$ of MSW, from which 7.23 millions $\mathrm{m}^{3}$ are to be removed by the system of HME (see Figure 1) [2].

Removal of $80 \%$ of waste from city territory is carried out by the large specialized enterprises "Spetstrans" equipped with modern machinery. The others $20 \%$ of waste are removed by forces and means of several tens of small carriers with which there are concluded contracts by the companies of proprietors of habitations and the housing co-operatives

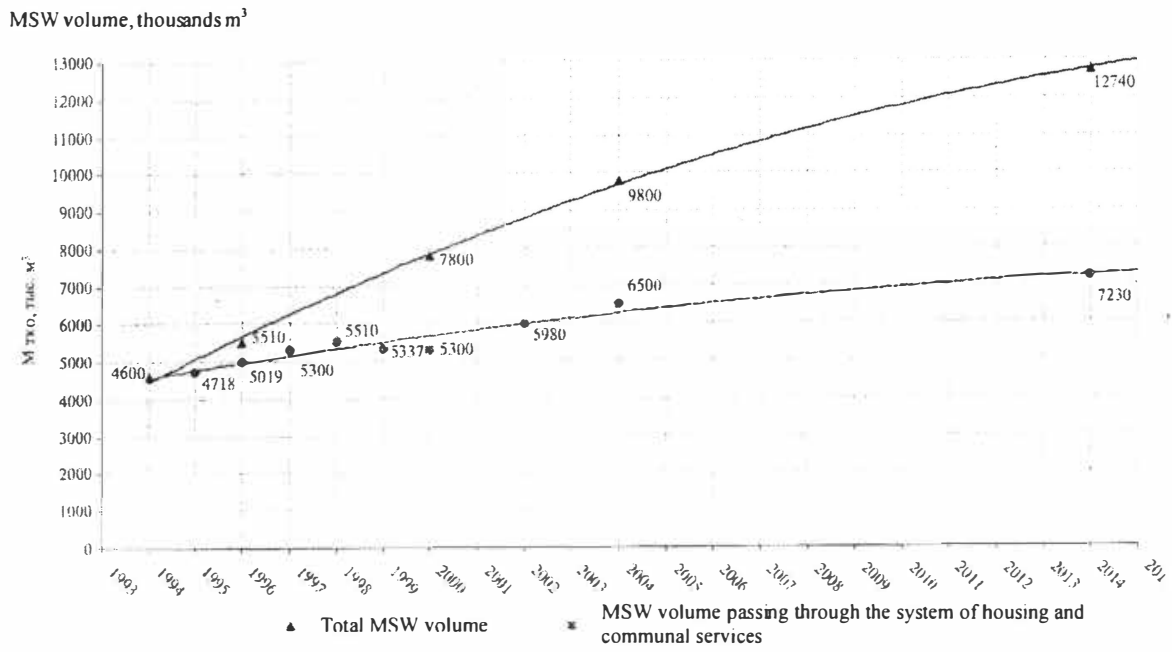

Figure 1. Prognosis of MSW formation in Saint-Petersburg for 2005 - 2015. 
which are in self-service. Small carriers operate practically without any control, therefore in the territory of the city and in the suburbs there continually arise spontaneous congestions of waste which belong to nobody and for which condition nobody takes care.

Enterprises "Spetstrans" use two stage system of MSW removal with waste reloading in containers of large capacity at six reloading stations.

The waste management is dispersed between several committees of Saint-Petersburg city administration that creates considerable difficulties since any of them is not responsible for decision of the problem as a whole. Besides, for the optimal organization of business in economic aspect Saint Petersburg needs a responsible managing company engaged in sphere of waste.

As the federal normative-and-legislative base on handling with waste has essential lacks (gaps, contradictions, etc.), there are necessary development and acceptance of regional laws and decisions of Saint-Petersburg governor which could compensate incompleteness of documents of a federal level.

Financial means for MSW collection and removal levy from the population as payment for services (the tariff in July, 2004 was 14.12 rubles per person). Charges on processing and a burying of waste of the population a re compensated due to the city budget. Payment of collection, removal and neutralization of waste of the enterprises, the organizations and private businessmen is made due to the producer of waste [2].

\section{USED EQUIPMENT AND METHODS OF MSW REMOVAL}

Open Company "Mechanical plant "Spetstrans" with assistance of the specialized enterprises Open Societies "Car Park № 1 "Spetstrans"” and "Car Park № 6 "Spetstrans"” has developed and has introduced the following methods of collection and transportation of municipal solid waste in Saint Petersburg [3]:

- Direct removal of municipal solid waste. A car takes away a container by manipulator and pours out its contents into a body, after filling car goes to a place of MSW neutralization. Pluses of this method are the strict schedule, an opportunity of service of containers at entrances, in districts with small waste accumulation and at enterprises of small-sized trade. Minuses of this method are low productivity (small coefficient of compaction), low reliability of cars, big expenditure of rubber and combustive-lubricating materials, spilling out waste at loading, complexity of regulation of containers quantity;

- Two staged system of removal of municipal solid waste. Garbage trucks of small carrying capacity work on a short shoulder of run, they reload MSW into containers-stores of the greater capacity at reloading stations on which there are established the presses, compacting refuse (waste). Stores are transported to the places of utilization. Pluses of this method are reduction of volume of transported waste, economy of combustive-lubricating materials. Minuses of this method are bad ecological condition of the territories which are situated near to the reloading stations, the lowest opportunity of use of the pressed waste for selection of secondary raw materials, conditions for unfair mixture of commercial refuse with housing one; 
- MSW removal with application of temporary reloading sites. In served microdistrict the temporary site is constructed, on which the garbage (refuse) truck of the large capacity (24 cubic meters) is established. The waste from the nearest containers before filling is unloaded to this garbage truck. The container is brought on a place of an overload or on a place of neutralization. It is the most economic method under the cost price of works;

- Removal directly from under refuse chutes. Tanks are rolled out to cars with lateral or back loading, or to pressers, combined with collection of secondary raw materials (this is a new direction of activity).

There are also carried out removal of large-sized refuse (waste) under the telephone application, containerless removal, removal of trading zones waste with use of pressers, collection and removal of secondary raw materials.

To the basic equipment being used when collecting and transporting municipal waste, they concern: containers; garbage trucks; reloading stations; compactors.

Waste reloading stations (see Table 1, [3]) are intended for reloading, pressing and removal of municipal solid waste to places of utilization or burial places in case of application of two staged technology of waste removal. Reloading stations can be supplemented with sorting lines for selection of processed and not processed fractions of waste (refuse) (refuse sorting stations) and also with lines on processing waste (refuse sorting complexes, plants). Reloading stations in Saint-Petersburg in the beginning represented little trestles where from small-sized collecting garbage trucks (6 cubic meters by volume) the refuse reloaded to large ones (27 cubic meters by volume) and was removed to a dump. Now Open Company "Mechanical plant "Spetstrans" produces special presses for compaction of garbage in 3-4 times at a stage of reloading and instead of 27 cubic meters of waste earlier, there are taken out by three axed cars up to 90 cubic meters per run and up to 120 cubic meters by four axed cars. Presses are equipped by electro-hydraulic drives with capacity up to $30 \mathrm{~kW}$ and have productivity up to 500 cubic meters per gang. The compacted garbage is transported in the special, closed containers in volume from 18 up to 30.5 cubic meters. If reloading station is equipped with a line of refuse separation, the presses are used for compaction of not processible part of garbage.

Compactors are the special devices of various capacity intended for separate collection of easy fractions of secondary raw materials (paper, cardboard, plastic), and also MSW accumulation with the purpose of reduction of costs at transportation [3].

\section{APPLIED TECHNOLOGIES ON MSW REMOVING}

Now, there are practised two variants of MSW removal in Saint Petersburg and suburbs.

Containerless removal has been practised as an experiment in Admiralteisky district since 1995. The given method provides receiving waste from the population to the reception bunker of garbage trucks. The variant of removal demands observance of the rigid traffic diagram of garbage trucks. Removal of waste is carried out two times day, during morning and evening time (from 7 up to 23).

Container removal is applied in all other districts. 
Variants of container removal: a) with use of containers by volume of 6 and 12 cubic meters; b) with use of constant containers by volume of $0.75 \mathrm{ml}^{3}$. Removable containers of large capacity are used for service of population in areas of new buildings and for enterprises. Nonremovable containers of small capacity are applied to service population in the central areas (districts) with high density of building and for a number of enterprises. The basic part of containers is on balance of the motor transportation enterprises engaged in waste removal. The types of containers are shown in Figure 2.

Service life of containers makes $4-5$ years. Up to $70 \%$ of containers pass annually preventive repair and painting that makes $30 \%$ of expenses from total amount of repair works. The percent of deterioration of container facilities of city makes $40 \%$. The percent of deterioration of garbage trucks makes $30 \%$. In Primorsky, Vyborgsky, Krasnosel'sky, Kurortny and Petrodvorets districts of Saint Petersburg in non-seweraged home ownerships, there are formed liquid municipal waste which are necessary to remove with the help of conservancy cars. These waste are taken out from rake-outs by cars of mark KO-503, KO-505, with the subsequent removal to the drain stations [3].

Table 1. Waste reloading stations

\begin{tabular}{|c|c|c|c|c|}
\hline Station & Address & $\begin{array}{l}\text { Capacity } \\
\left(\mathrm{m}^{3} / \text { day }\right)\end{array}$ & $\begin{array}{l}\text { Area, } \\
\text { (ha) }\end{array}$ & District of service \\
\hline $\begin{array}{l}\text { Nol, } \\
\text { MTE-1 }\end{array}$ & $\begin{array}{l}\text { Predportovaya } \\
\text { street, } 6\end{array}$ & 3000 & 1.6 & Moskovsky, Kirovsky, Frunzensky \\
\hline $\begin{array}{l}\text { No2, } \\
\text { MTE-1 }\end{array}$ & $\begin{array}{l}\text { Shkipersky Canal } \\
\text { street }\end{array}$ & 1000 & 0.5 & $\begin{array}{l}\text { Vasileostrovsky, } \\
\text { Central'ny }\end{array}$ \\
\hline $\begin{array}{l}\text { No3, } \\
\text { MTE-6 }\end{array}$ & Avtobusny lane, 2 & 931 & 1.5 & $\begin{array}{ll}\text { Petrogradsky, } & \text { Primorsky, } \\
\text { Kalininsky, Vyborgsky } & \\
\end{array}$ \\
\hline $\begin{array}{l}\text { No4, } \\
\text { MTE-6 }\end{array}$ & $\begin{array}{l}\text { Dal'nevostochny } \\
\text { prospect, 3a }\end{array}$ & 944 & 0.2 & $\begin{array}{l}\text { Central'ny, } \\
\text { Krasnogvardeysky }\end{array}$ \\
\hline $\begin{array}{l}\text { No5, } \\
\text { MTE-6 }\end{array}$ & $\begin{array}{l}\text { Leontjevsky } \\
\text { Capelet street }\end{array}$ & 180 & 0.4 & Petrogradsky \\
\hline $\begin{array}{l}\text { No6, } \\
\text { MTE-6 }\end{array}$ & $\begin{array}{l}\text { Mitrofanjevskoye } \\
\text { Highway street }\end{array}$ & reserve & 0.3 & $\begin{array}{l}\text { Krasnosel'sky, } \\
\text { Central'ny }\end{array}$ \\
\hline $\begin{array}{l}\text { No7, } \\
\text { MTE-6 }\end{array}$ & $\begin{array}{l}\text { Area of railway } \\
\text { station «Ruchji» }\end{array}$ & $\begin{array}{c}1500 \text { in } \\
\text { perspective }\end{array}$ & 1,5 & Kalininsky lane \\
\hline
\end{tabular}

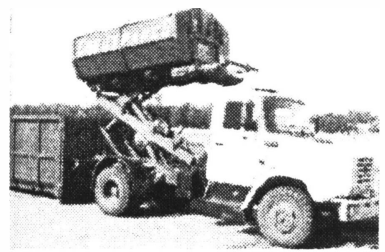

a. Main containers by capacity of 6 and $27 \mathrm{~m}^{3}$

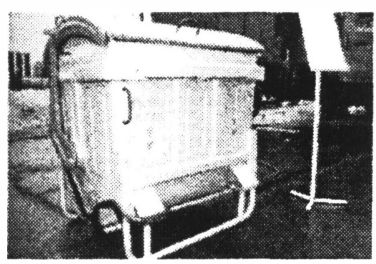

b. Small «European» container $0,75 \mathrm{ml}^{3}$

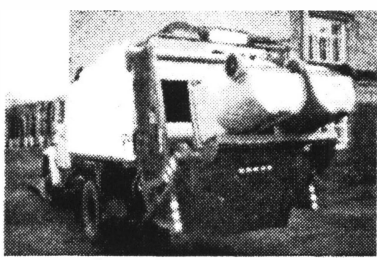

c. Loading from small containers to pressing garbage truck

Figure $2(a, b, c)$. Different kind of containers for municipal solid waste collection 


\section{LACKS OF CONTEMPORARY SYSTEM OF MSW COLLECTION AND REMOVAL}

There are following basic questions, not solved by managing and housing-maintaining organizations:

It is done very little for maintenance of separate collection of utilized MSW components with the help of special collectors;

There are not created special collectors for dangerous components subjected to removal from MSW content;

The issue of collection, temporary storage and removal of oversized refuse is not solved, that as well periodically and especially during the spring period caused pollution of territory, including pollution because of burning waste;

The housing-operational organizations have not settled mutual relation with the rent enterprises and subjects of enterprise activity, housing co-operatives on the issues of collection and temporary storage of municipal solid waste;

Existing container sites, frequently, do not meet requirements of Sanitary Rules and Norms (repairs of sites, protections, containers are performed out of time);

Technical condition of containers, frequently, does not meet requirements of Sanitary Rules and Norms since, in overwhelming majority of the cases, used containers are not equipped with covers;

The issue of washing containers is not solved;

The issues of cleaning, washing, disinfection, disinsection and deratization of existing refuse chutes (mines of refuse chutes and refuse receiving capacities) are not solved.

All higher listed aspects create conditions not only for pollution of ground settlement territories, but also promote duplication of insects and rodents, thus, complicating an epidemiological situation in Saint Petersburg.

\section{PERSPECTIVES OF DEVELOPMENT OF THE COMPLEX OF COLLECTION AND TRANSPORTATION OF WASTE}

In opinion of administrations of parks, they are capable to increase volume of processable refuse in 1,5-2 times on existing base.

Till recent time all refuse of tenants of inhabited and uninhabited fund had been taken out due to budgetary funds of our city. Nowadays the order of the governor of Saint Petersburg the situation is to be change radically. It is now being carried out, and it will be carried out further the work on conclusion of direct agreements with "manufacturers" of garbage: from 250 thousands city enterprises, 10 thousands have already concluded such agreements with the specialized enterprises. 
Besides, that significant part of MSW is pressed before removal to the enterprises on MSW processing up to threefold reductions of volume, the weight of taken out refuse can exceed some 1 million tons, that corresponds to its annual formation in present time and projected perspective in 25 years. Due to this, it is not required substantial growth of a number of the vehicles which are taking part in operation.

Diffierently is the question with quality and structure of technical means. Deterioration of special cars and containers too slowly updated during $1998-2000$, exceeded $80 \%$. To the beginning of 2001 there was a situation at which restoration of the given sphere of managing became an absolute necessity. For last 2 years, according to the information of administration of Open Society "Car Park № 6 "Spetstrans"", due to leasing bank credits was possible to fill up the park, approximately by 100 units of cars and equipment so-called "the third generation". Thus, there has been updating approximately $33 \%$ of a rolling stock. This process has been continuing, and due to realization of the second stage of crediting it is supposed to update about $66 \%$ of a rolling stock and containers.

At development of sorting of waste at reloading stations, it is necessary to pass from primitive manual sorting to mechanical means. Complexes of technical equipment are made for this purpose both by domestic and foreign enterprises.

At the enterprise it is paid special attention, both to perfection, and development of new cars and containers. So now, there are conducted the works on construction of new types of containers which are called compactors, studies on equipment of transport by navigating systems, etc.

In the result, there have been constructed the technical equipment and technology of "new generation" which come nearer to a global level. It is garbage truck MAZ-MSK-16-T with the container of $31 \mathrm{ml}^{3}$, which is introduced into manufacture, a garbage truck on the base of ZIL car with the diesel engine and the equipment for pressing municipal waste, a garbage truck with the manipulator for work with so-called "eurocontainers", the equipment and installations for pressing municipal waste.

Now at Mechanical plant "Spetstrans" at participation of experts of the Car Park, there has been created the car for service of the center of Saint Petersburg which is represented by areas of few-storey buildings. Application of these cars will allow to lower expenses for waste removal on the average for $20 \%$ therefore saving the petroleum products, to reduce extent of routes of movement, and by that to improve city ecological conditions.

There are carried out negotiations with experts of KAMAZ for creation of the new chassis with the raised opportunity of economy of fuel, and work on creation of new kinds of containers on wheels of European standard type. The special attention of specialists of motor transportation enterprises (MTE) Nol and No6 is given by MTE experts to transition to a two-phasic method of removal of waste with use of refuse reloading stations, to construction of the various processing equipment for compaction and pressing waste.

Through reloading stations passes up to $50 \%$ from total amount of the taken into account waste. Practice of use of such stations has shown their expediency and perspectivity for reduction of a shoulder of run few-tonnage garbage truck transport, reduction of transport charges and reduction in tariffs for waste removal. 
At reloading stations there are established 16 presses with coefficient of compaction from 4 up to 8 .

The wide set of constructive and technological decisions on mechanization of sorting MSW presumes in each concrete case, proceeding from architectural-design structure of city building, financial and economic opportunities and ecological conditions to choose the most effiective method of the organization of sanitary clearing practically for any district or area of city.

At the enterprise it is developed, introduced and successfully operates the system of global satellite positioning (satellite dispositional system SDS-2) which allows carrying out the analysis of site of special cars on a line each 10 seconds with accuracy of 10 meters. In the result the strict control over moving and places of unloading of ecologically dangerous cargoes is provided.

Application of SDS-2 allows supervising: where the cargo is received, by what way it was transported, whether is taken to a place of utilization in the put terms. The "black box" costs about 1000 dollars. But economic benefit and the main thing, which is creation of uninterrupted system of the ecological control, justify the spent financial means [3].

The organization of collection, transportation and sorting of MSW that exists today and is going to be in 2009 and 2014 is schematically shown in Figure 3. Development of system of MSW processing and placement for forthcoming 9 years is resulted in Figure 4, [2].

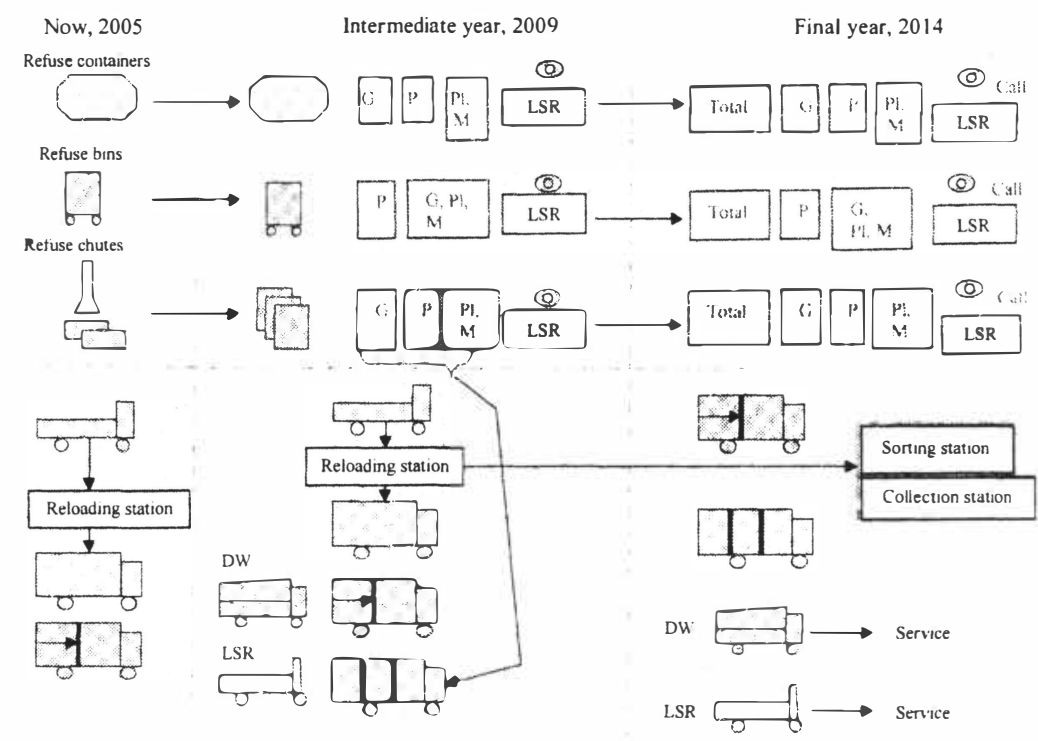

Figure 3. Scheme of development of organization of collection, transportation and sorting of MSW in Saint-Petersburg in the period from 2004 till 2014 years:

$G$ - glass, $P$ - paper and cardboard, Pl - plastic, $M$ - metals, LSR - large-sized refuse (waste), DW-dangerous waste. 


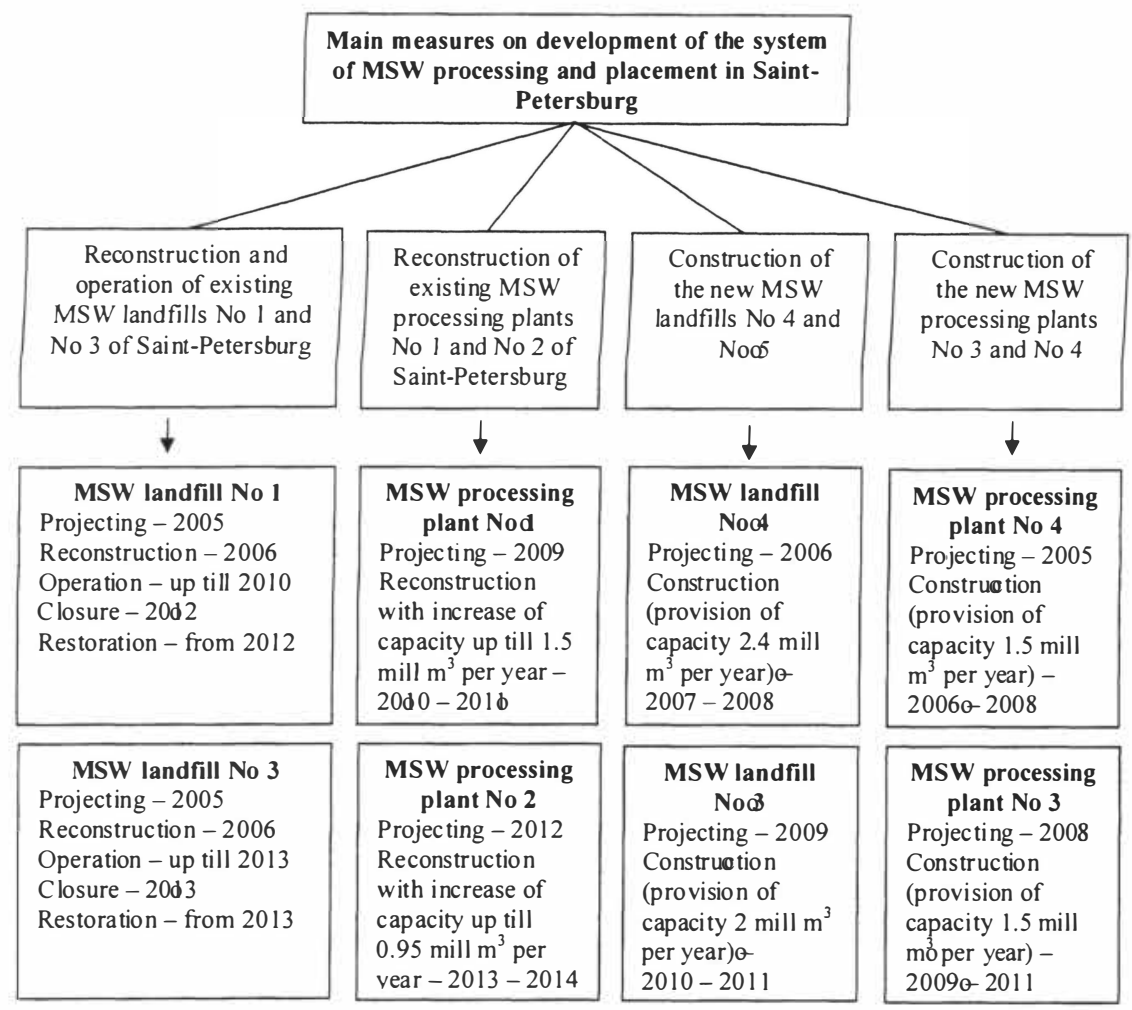

Figure 4. Development of the system of collection and placement of MSW in Saint-Petersburg up till 2014.

\section{CONCLUSIONS}

According to the conclusions contained in "Concept of Handling with Municipal Solid Waste in Saint Petersburg for 2005 - 2014" [1], during the ten years' period there should be carried out in Saint Petersburg transition to industrial processing all municipal solid waste formed in the city. For realization of the "Concept" there has been developed "Program of Measures on Optimal Development of the System of Handling with Municipal Solid Waste in SaintPetersburg for 2005 - 2014" and "Plan of measures" corresponding to the program where there are stipulated actions on the basic directions of development of the given sphere of municipal economy which should be carried out for achievement of the purposes put in the "Concept".

As to technological measures in the field of collection and transportation of waste there are planned: 1) to update park of the containers intended for collection and transportation of waste, and park of cars (automobiles-garbage trucks) with their replacement by more perfect marks and designs, including their replacement for machines (cars) with premoulding waste $(2005-2007) ; 2)$ to organize separate collection of dangerous waste in home economy sector 
of all districts (areas) of the city, for what: a) to develop and use in practice the specialized containers for collection of exhausted chemical sources of a current which are batteries and accumulators (2006 - 2007), to organize in the city the system of collection and removal of the municipal waste containing mercury (2005 - 2007); 4) to organize in areas of new building city separate collection of waste at existing container sites or to create special sites for MSW collection and preliminary sorting with allocation of secondary raw materials (2006 $-2008)$; 5) to establish containers for separate collection secondary raw materials in the areas of home economy sector of old building $(2006-2007) ; 6)$ to organize in the areas of the city the specialized sites for collection of large-sized, building and dangerous waste of a household (municipal) origin $(2006-2007) ; 7)$ to organize in the areas of city the specialized sites for temporary placement of the collected automobile (cars) bodies which have come in unsuitability, and the worn out automobile trunks $(2006-2009) ; 8)$ to analyze a condition, equipment and functioning of existing waste reloading stations (see Table 1 ) and in view of results of the analysis to carry out their reconstruction, and in case of need to increase number of such stations (2005 - 2014); 9) with a view of the accelerated realization of measures on allocation from waste of dangerous fractions and secondary raw materials to organize in territory, adjoining to the ring automobile motorway, four sorting stations with capacity of 75 thousands tons per year everyone for reception and sorting of such waste selectively collected by the population $(2006-2008)$; 10) to create system of an effiective control for observance of rules and norms of transportation of waste of all carriers of the city (2005 - 2006) [2]t

Management of flows of waste of the megacity as Saint-Petersburg, is impossible without reception and processing of the operative information on waste from all its districts (areas). Therefore it is necessary to start urgently creation of the automated directory system under on handling with waste in Saint-Petersburg which will enable operatively to keep account their formation, accumulation, transportation and placement.

\section{REFERENCES}

[1] Ventsiulis, L. S., Florinskaya, T.M. and others, 2002. Concept of Handling with Waste in Saint-Petersburg. Saint-Petersburg Scientific Center of RAS, Saint-Petersburg, Russia, pp. 27 - 34 (in Russian).

[2] Golubev, D.A., Sorokin, N. D. and others, 2005. Environmental Protection, Nature Management and Environmental Safety Provision in Saint-Petersburg. Committee on Nature Management, Environmental Protection and Environmental Safety Provision of Saint-Petersburg, Saint-Petersburg, Russia, pp. 267 - 298 (in Russian).

[3] Stebulianin, R. A., Yershov, S. D., 2004. Technic and Economy Substantiation of the "Plan of Nature Protective Measures When Handling with Municipal Solid Waste of Saint-Petersburg". Open Society "Ore Metallurgical Company "Noril'sky Nickel"”, Saint-Petersburg, Russia, pp. 14 - 31 (in Russian). 